\title{
Purification of The Antitumor Active Metabolite from Streptomyces xylophagus Ha.Ph-7 Crude Extract Isolated from Hamam Pharaoh Hot Spring Saad AM Moghannem ${ }^{1 *}$, Kouka SE Abd-elwahab ${ }^{2}$, Hussein H Elsheikh ${ }^{3}$ \\ ${ }^{1,3}$ Botany and Microbiology Department, Faculty of Science, Al_Azhar University,Cairo, Egypt. ${ }^{2}$ Virology Laboratory, Microbiology Department, Faculty of Medicine for Girls(FMG), Al_Azhar University, Cairo, Egypt.
}

\section{ABSTRACT:}

Aim: This study aimed at production, extraction, purification and characterization of active antitumor compound from marine actinomycete secondary metabolites crude extract that was selected as most potent crude secondary metabolites from the preliminary screening of total fifty one extract.

Material and methods: These tumor cell lines were breast cancer (MCF-7) (ATCC HTB-22) and Hepato-cellular carcinoma (HepG2) (ATCC 77400), colon cancer (Caco) (ATCC HTB-37) and cervix carcinoma (HeLa) (ATCC CRL-13011) cells. Purification process was done using silica gel column chromatography while purity was detected using thin layer chromatography (TLC). The active fraction was detected using morphological changes (cytotoxicity) by microscopic examination and anti-proliferative activity using MTT [3-(4,5-dimethylthiazol-2-yl)-2,5-diphenyltetrazolium bromide] assay.

Result: The result indicated that there is only one fraction responsible for antitumor activity. This active fraction has cytotoxic and anti-proliferative activity against HepG2, MCF7, Caco and HELA cells with IC50=24.5, 20.1, 27.6 and $17.7 \mu \mathrm{g} / \mathrm{ml}$ respectively. The analysis of physico-chemical, elemental and spectroscopic analysis (UV, IR, H.NMR, Mass spectroscopy) indicated that; the active compound has the nature of anthracycline compound.

Conclusion: This purified compound has promising broad spectrum cytotoxicity and antiproliferative activity in an in vitro system. The next research step shall include different optimization parameter that maximize productivity with long-term goal; discovery of an antitumor drug from actinomycetes native to Egyptian hot springshabitat.

Key words: Actinomycete extracts, antitumor, Cytotoxicity, Anti-infectivity, HepG2, Caco, MCF7, HELA.

Email: $\underline{\text { saad_moghannem@yahoo.com }}$

\section{INTRODUCTION:}

Actinobateria represents one of the largest taxonomic units among the 18 major lineages currently recognized within the domain Bacteria [1]. In addition, the isolation of marine actinomycetes has been a great source of new compounds and their isolation all around the globe, from shallow costal sediments to the deepest sediments from the Mariana Trench, demonstrates that actinomycetes are ubiquitous in marine sediments, but at lower numbers than in soil [2-14]. Progress has been made recently on drug discovery from actinomycetes by using high-throughput screening and fermentation, mining genomes for cryptic pathways, and combinatorial biosynthesis to generate new secondary metabolites related to existing pharmacophores [15]. Marine actinomycetes have attracted great attention since they have developed unique metabolic and physiological capabilities that not only ensure survival in extreme habitats, but also offer the potential to produce compounds with antitumor and other interesting pharmacological activities that would not be observed in terrestrial microorganisms [16-20], perhaps because of their close relationships with marine eukaryotic organisms including mammals[2,9]. Polyketides are a large family of natural products produced by step-wise decarboxylative Claisen type condensation of acyl-CoA precursors, reactions catalyzed by polyketide synthases (PKSs). Three types of PKSs are known to date: type I PKSs are multifunctional enzymes organized into modules, type II PKSs are multienzyme complexes carrying out a single set of activities and type III PKSs, also known as chalcone synthase-like PKSs, are iteratively acting condensing enzymes [21]. In addition anthracyclines represent a wide family of compounds with indicator-like properties, red in acid and blue-violet in alkaline solution, that are produced by cultivation of microorganisms belonging to the genus Streptomyces [22] Anthracyclines are among the most effective and widely prescribed anticancer agents [23]. Anthracycline has three mechanisms of action: 1- Inhibits DNA and RNA synthesis by intercalating between 
base pairs of the DNA/RNA strand, thus preventing the replication of rapidly-growing cancer cells. 2- Inhibits topoiosomerase II enzyme, preventing the relaxing of supercoiled DNA and thus blocking DNA transcription and replication. 3- Creates ironmediated free oxygen radicals that damage the DNA and cell membranes [24].

\section{MATERIAL AND METHODS:}

\section{Production of Extracellular Bioactive Metabolites:}

Spores from five to seven days old culture of the selected actinomycete isolates were used to inoculate $250 \mathrm{ml}$ Erlenmeyer flask containing $100 \mathrm{ml}$ of the fermentation medium (liquid starch-nitrate nutrient medium, $\mathrm{pH}=$ 7). The seeded flasks were incubated at $30-$ $33{ }^{\circ} \mathrm{C}$ for 7 days at submerged conditions. After the incubation period, the fermentation broth was harvested and filtered through cotton wool then; the clear filtrate was exposed to the extraction process.

\section{Extraction of Extracellular Bioactive} Metabolites:

The collected filtrate $(20.0$ liters $)$ of Streptomyces xylophagus $\mathrm{Ha} \cdot \mathrm{Ph}-7$ was extracted with chloroform : Ethanol solvent system $(2: 1 \mathrm{v} / \mathrm{v})$ in a separating funnel. The lower layer was separated and collected then the solvent was evaporated under reduced pressure using a rotary evaporator. The evaporation process was continued until deep brown viscous syrup (3.9 gm) was obtained.

Bioactivity-guided fractionation of the crude extract obtained from Streptomyces xylophagus Ha.Ph-7.

Fractionations of the crude extracts obtained from Streptomyces xylophagus Ha.Ph-7 using silica gel column chromatography.

Three grams of the crude extracts was dissolved in the least amount of the eluting solvent (Ethanol/chloroform mix) and applied to silica gel column $(3.5 \times 40 \mathrm{~cm})$, then eluted with a gradient solvent ratios (table: 1 )

Fifty $\mathrm{ml}$ fractions were collected then fractionated using TLC analysis. The fractions that have similar TLC profiles were pooled to give finally a total of 13 fractions (Table: 2).

\section{Cell culture:}

HepG2 cells (ATCC 77400) passage number 40, MCF-7 (MCF-7) (ATCC HTB-22) passage number 32, colon cancer (Caco)(ATCC HTB-37) passage number 25 and cervix carcinoma (HeLa)(ATCC CRL-
13011) passage number 29 were obtained from cell culture bank at the Holding Company for Biological Product and Vaccine (VACSERA) and maintained in our lab from passage number 40-51 for HepG2, 32-40 for MCF7, 25-39 for Caco and 29-43 for HELA. The medium used was Dulbecco's modified Eagle's medium (DMEM, GIBCO, USA). All cells were supplemented with $10 \%$ Foetal bovine serum (FBS) and antibiotics (100IU penicillin and 100IU streptomycin /ml) solution and maintained with $2 \%$ FBS and antibiotics solution and incubated at $37^{\circ} \mathrm{C}$ and $5 \% \mathrm{CO}_{2}[25]$.

Cytotoxicity and Anti-proliferative Assays: Cells (Caco, HELA and MRC5) were seeded in 96-well plates at the density of 1000 cells/well in $100 \mu \mathrm{l}$ medium except on column (8 wells) without cells as blank and incubated at $37^{\circ} \mathrm{C}$ for 24 hour in $5 \% \quad \mathrm{CO}_{2}$ for the formation of confluent monolayer. The monolayer of cells in the plate was exposed to various dilutions of the secondary metabolite extract $(100,90,80,70,60,50,40,30,20,10$, $5,1 \mu \mathrm{g})$ except another column ( 8 wells) seeded with cells only as positive control and incubated at $37^{\circ} \mathrm{C}$ for 24 hour in $5 \% \mathrm{CO}_{2}$. After 24 hour incubation the cytotoxic effect of different microbial extracts are visualized under inverted microscope before proceeding with MTT assay protocol. Then $20 \mu \mathrm{l}$ of MTT reagent was added to each well and incubated for additional 4 hour. Then $180 \mu 1$ of DMSO solution was added to each well to solubilize the formazan crystals. The cell viability was measured using MTT assay (3-(4,5dimethylthiazol-2-yl)-2,5-diphenyltetrazolium bromide) with MTT $(5 \mathrm{mg} / \mathrm{ml})$ and DMSO. This tetrazolium salt is metabolically reduced by viable cells to yield a purple insoluble Formozan product measured at $570 \mathrm{~nm}$ spectrophotometrically [26]. The assay was performed in triplicate for each of the extracts. The mean of the cell viability values was compared to the control to determine the effect of the extract on cells and \% cell viability form this equation:

$$
\begin{aligned}
& \text { Survival rate } \%=\frac{A \text { sample }-A_{b}}{A_{c}-A_{b}} \times 100 \\
& A_{c}=\text { Negative control } \\
& A_{b}=\text { Blank }
\end{aligned}
$$

Then the $\%$ of cell viability was plotted against concentration of different extract to calculate the IC50 values of each extract required to kill $50 \%$ of cancer cells. 
RESULTS AND DISCUSSION:

Bioactivity evaluation of the fractions obtained from the crude extract Streptomyces xylophagus Ha.Ph-7.

The obtained fractions from column chromatography were tested for cytotoxicity and anti-proliferative activity against HepG2, MCF7, Caco and HELA cell lines. Fractions that inhibit cell growth at concentration similar to that obtained with crude extracts survey are considered active (the fraction that exhibit activity at IC50<30 $\mu \mathrm{g} / \mathrm{ml}$ ) according to the American National Cancer Institute (NCI) guidelines in which IC50 $<30 \mu \mathrm{g} \mathrm{mL}^{-1}$ in the preliminary assay is considered active [27]. The IC50 value shows the inhibition concentration at which only $50 \%$ of the cells are viable. It was reported that crude materials that require a drug concentration greater than $30 \mu \mathrm{g} \mathrm{ml}^{-1}$ to exhibit cytotoxicity were not considered as cytotoxic agents [28]. It was recommended the survey of actinomycete extracts over a panel of cell lines Then antitumor activity is judged as the ability of the test substance to selectively kill (cytotoxic) or inhibit the growth (antiproliferative) of certain cell lines, rather than general cytotoxicity to all or most cell lines of the panel [29]. Therefore, among all studies the most cytotoxic potential with an IC50 value $<30 \mu \mathrm{g} \mathrm{mL}-1$ is considered active and should be selected for the next step of research.

Antitumor activity of the fractions obtained from the crude extract of Streptomyces xylophagus Ha.Ph-7 against HepG2 cells.

It was found that the fraction $(S-12)$ revealed cytotoxic activity against Hepatocellular carcinoma (HepG2) cell line with IC50 $=24.5$ $\mu \mathrm{g} / \mathrm{ml}$ while other fractions failed to exhibit any IC50 value even at concentrations up to $30.0 \mu \mathrm{g} / \mathrm{ml}$, which is a value higher than those of the crude extract (figure:1).

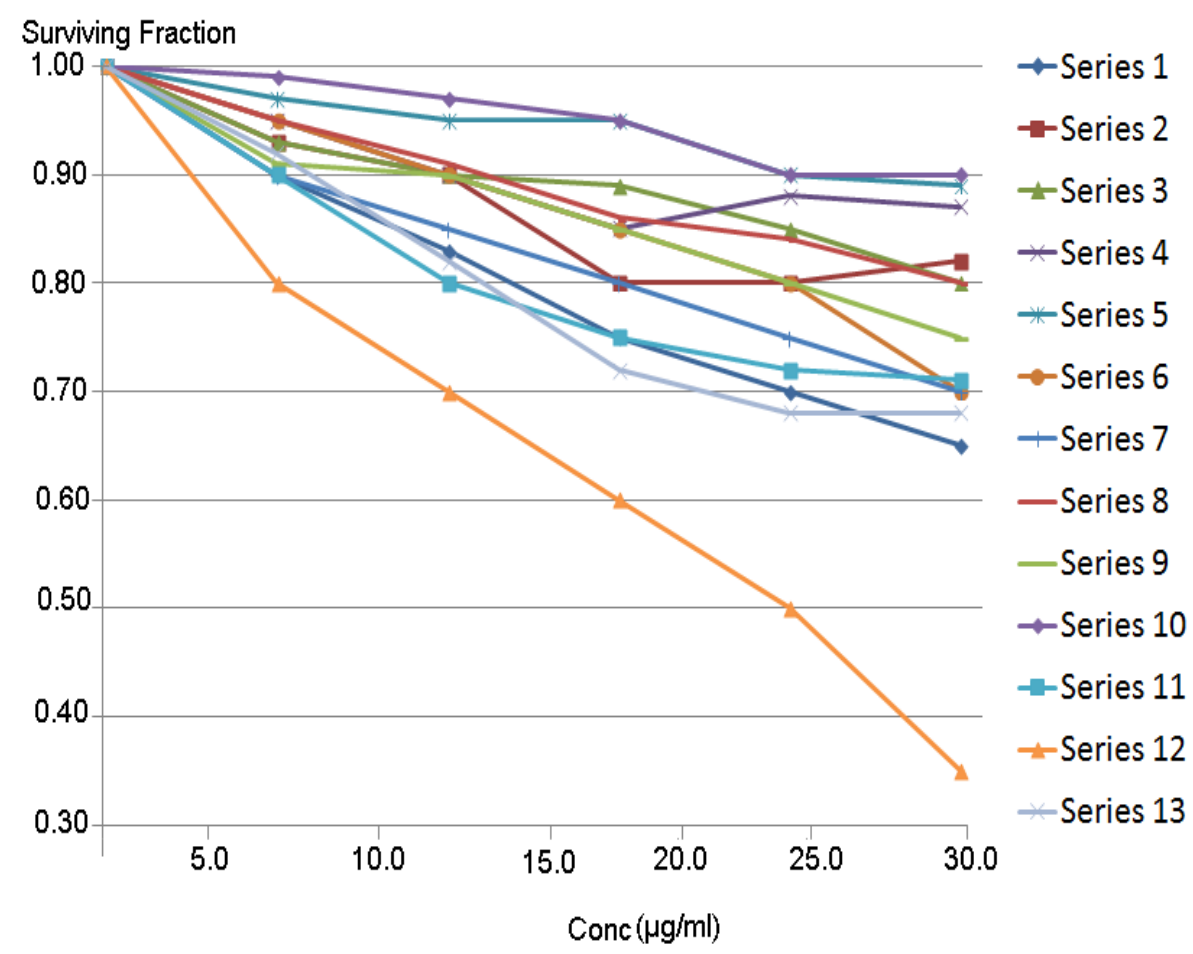

Figure (1): Cytotoxicity profile of the bioactive fractions of Streptomyces xylophagus Ha.Ph7against HepG2 cell line. 
Antitumor activity of the fractions obtained from the crude extract of Streptomyces xylophagus Ha.Ph-7 against MCF7 cell lines.

It was found that the fraction (S-12) revealed cytotoxic activity against MCF7 cell line with IC50= $20.1 \mu \mathrm{g} / \mathrm{ml}$ while other fractions failed to exhibit any IC50 value even at concentrations up to 30.0 $\mu \mathrm{g} / \mathrm{ml}$, which is a value higher than those of the crude extract (figure: 2 ).

Antitumor activity of the fractions obtained from the crude extract of Streptomyces xylophagus Ha.Ph-7 against Caco cell lines.

It was found that the fraction ( $\mathrm{S}-12$ ) revealed cytotoxic activity against Caco cells with $\mathrm{IC} 50=27.6$ $\mu \mathrm{g} / \mathrm{ml}$ while other fractions failed to exhibit any IC50 value even at concentrations up to $30.0 \mu \mathrm{g} / \mathrm{ml}$, which is a value higher than those of the crude extract (figure: 3 ).

Surviving Fraction

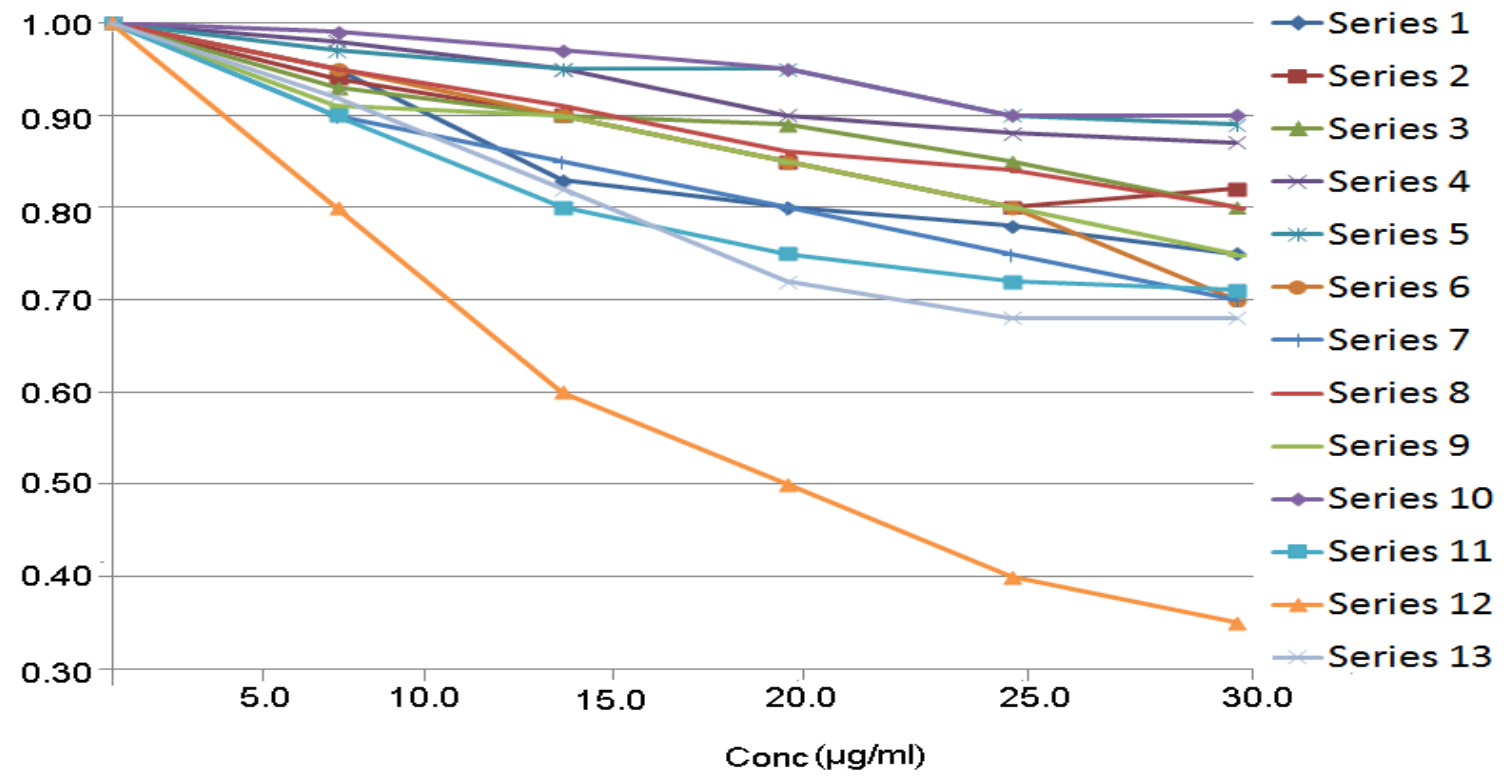

Figure (2): Cytotoxicity profile of the bioactive fractions of Streptomyces xylophagus Ha.Ph-7 against MCF7cell line

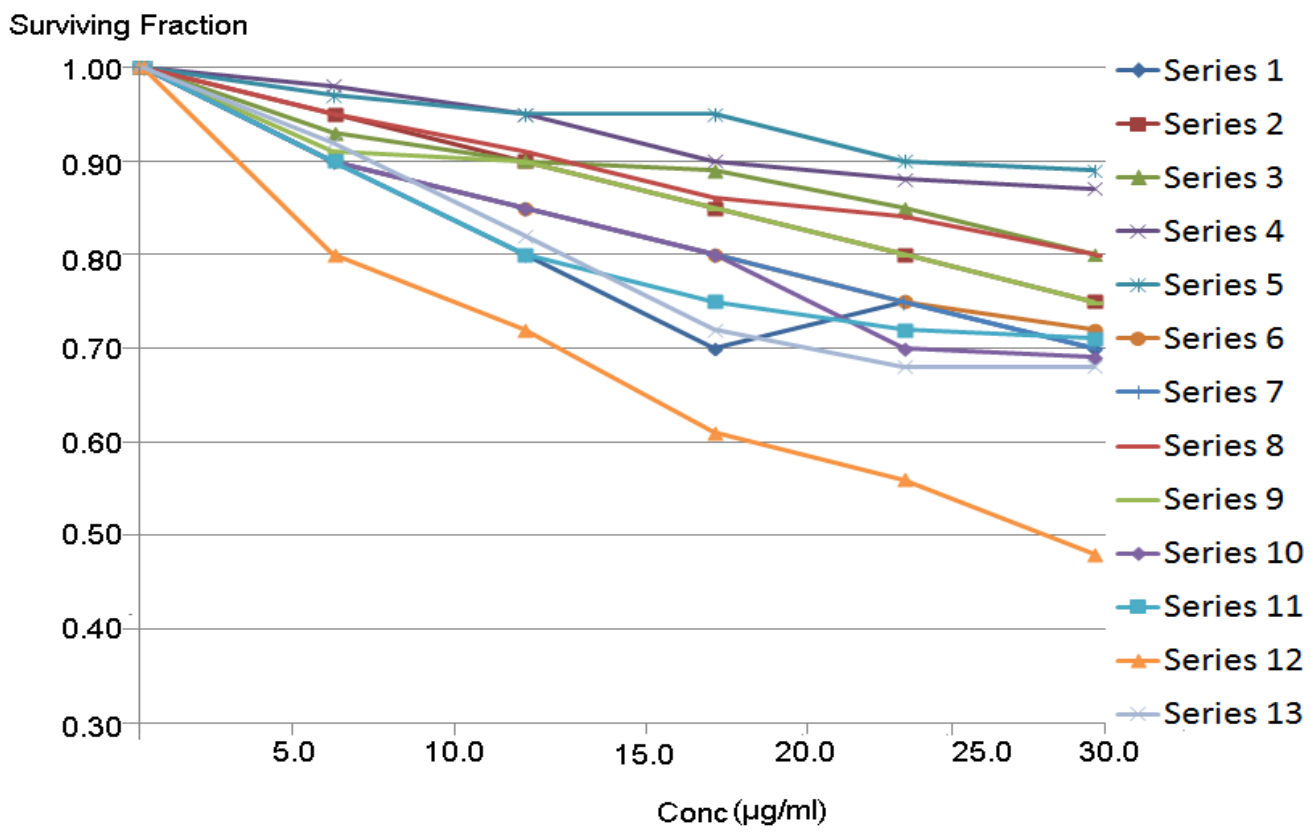

Figure (3): Cytotoxicity profile of the bioactive fractions of Streptomyces xylophagus Ha.Ph-7 against Caco cell line 
Antitumor activity of the fractions obtained from the crude extract of Streptomyces xylophagus Ha.Ph-7 against HELA cell lines.

It was found that the fraction ( $\mathrm{S}-12$ ) revealed cytotoxic activity against HELA cells with IC50 = 17.7 $\mu \mathrm{g} / \mathrm{ml}$ while other fractions failed to exhibit any IC50 value even at concentrations up to $30.0 \mu \mathrm{g} / \mathrm{ml}$, which is a value higher than those of the crude extract (figure:4).

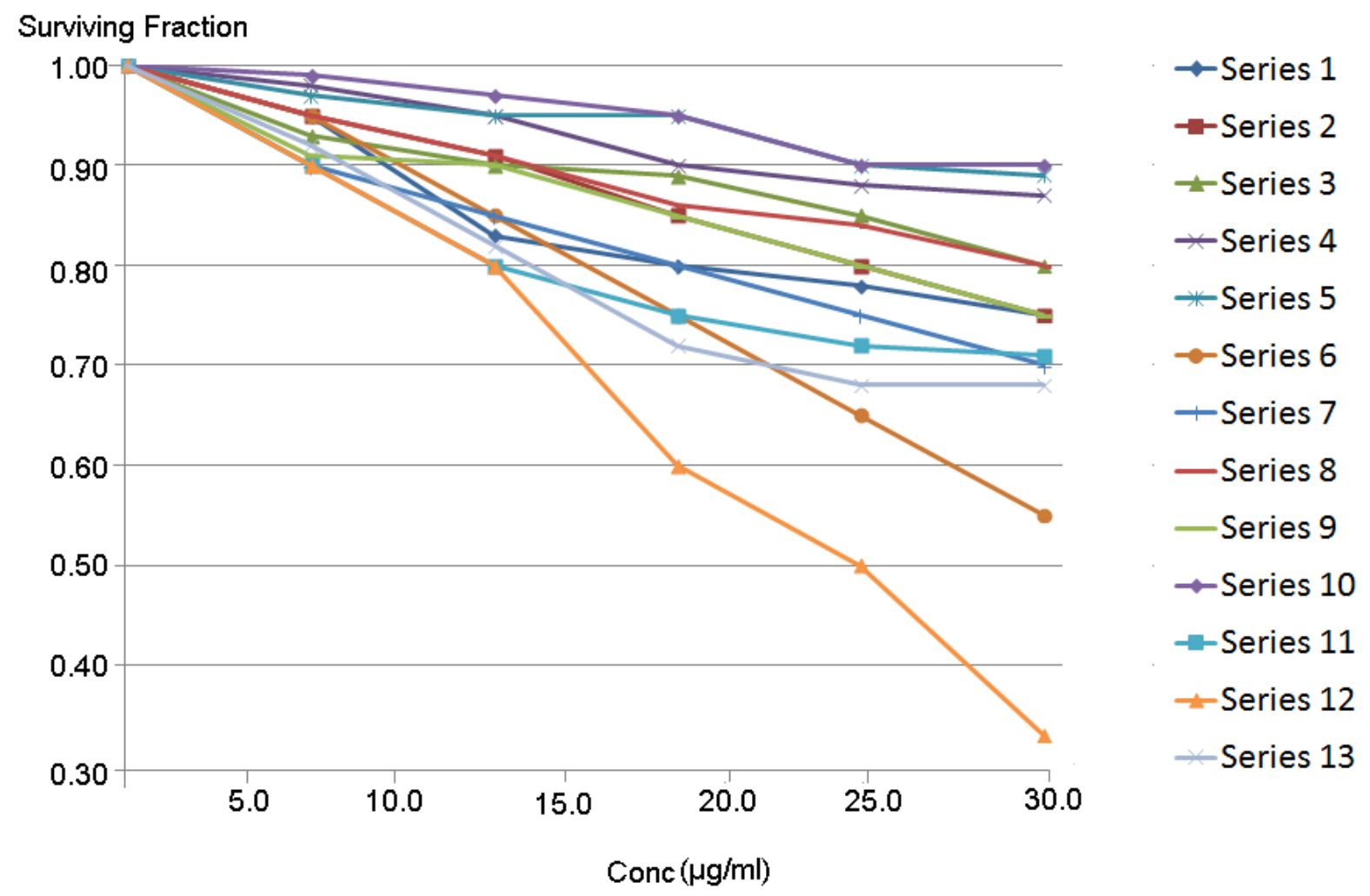

Figure (4): Cytotoxicity profile of the bioactive fractions of Streptomyces xylophagus Ha.Ph-7 against HELA cell line.

The TLC plate of the obtained compound (C-1) is illustrated in the following figure:

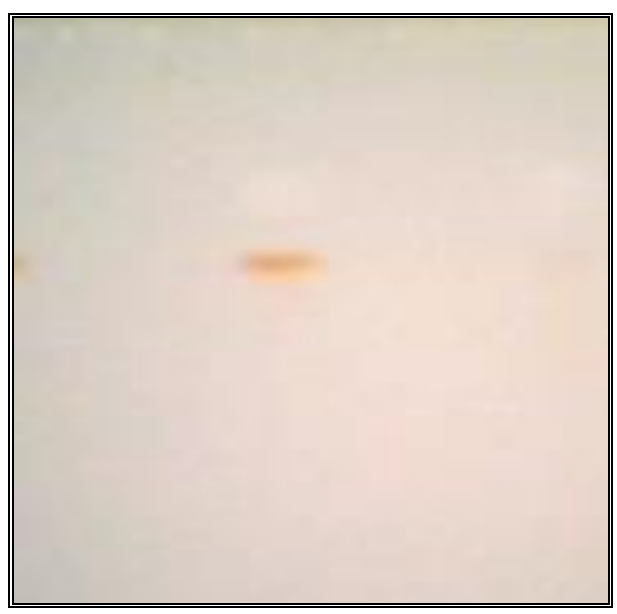

Figure (5): TLC plate of compound (C-1). 
Identification of the purified active compound obtained from Streptomyces xylophagus Ha.Ph-7.

\section{Physicochemical characteristics:}

The purified compound was isolated as amorphous red powder with no characteristics odor, red in acidic and blue-violet in alkaline solution, melting point is $145-155^{\circ} \mathrm{C}$. The compound is freely soluble in chloroform, ethyl acetate, ethyl alcohol and methanol and insoluble in petroleum ether, hexane and benzene and water.

\section{Spectral characteristics:}

Structural elucidation of the purified compound could be achieved by analysis of UV, IR, 1HNMR and Mass spectrum.

The ultraviolet (UV) absorption spectrum of the active substance in methanol using Perkin-Elmer Lambeda $15 \mathrm{UV} / \mathrm{V}$ spectrophotometer, exhibit maximum absorption peaks at 237nm (Figure: 6).

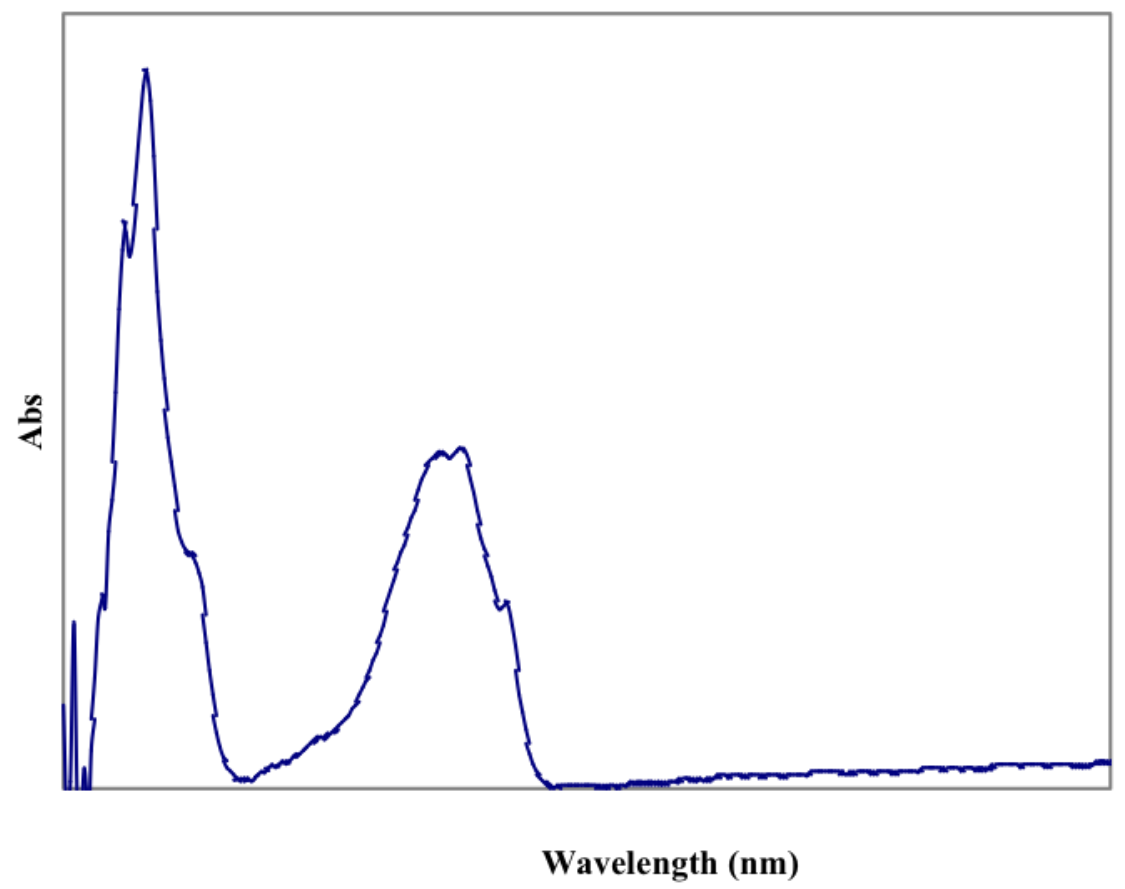

Figure (6): UV spectrum of the purified compound

The IR spectrum of the purified compound in (KBr) vmax showed: 668, 1026, 1554, 1646, 2358, $3344,3612,3732$ and $3802 \mathrm{~cm}-1$ figure (7). 


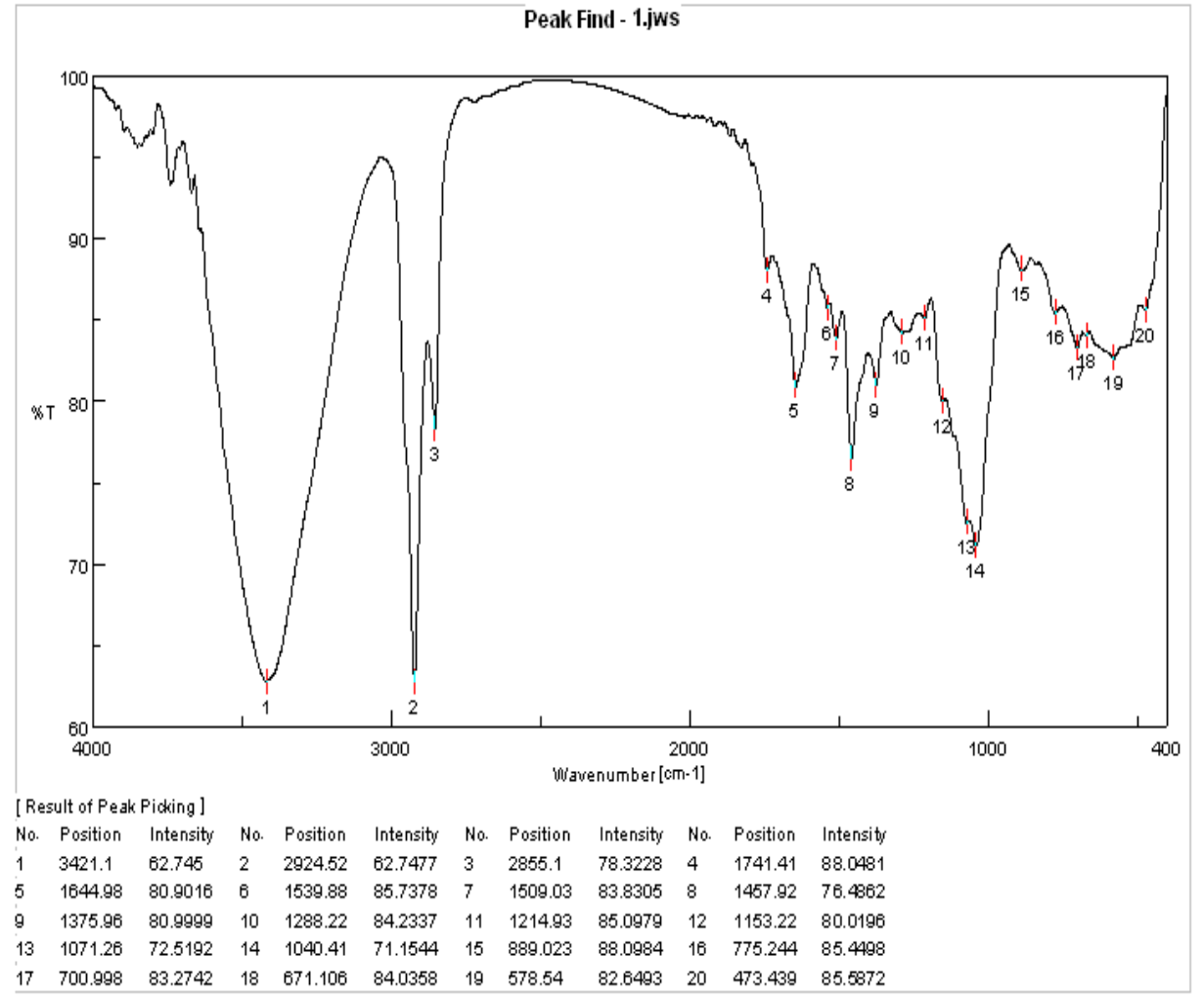

Figure (7): IR spectrum of compound $(\mathrm{C}-1)$ in $\mathrm{KBr}$.

1HNMR spectrum of compound $(\mathrm{C}-1)$ in $\mathrm{CDCl}_{3}$ exhibited the following signals at $\delta: 0.04-0.0144$ $\left(\mathrm{m}, 3 \mathrm{H}, \mathrm{CH}_{3}\right) ; 0.87-0.928\left(\mathrm{~m}, 2 \mathrm{H}, \mathrm{CH}_{2}-\mathrm{CH}_{3} \mathrm{CH}_{2} \mathrm{CHOH}\right) ; 1.2446$ (s, $\left.1 \mathrm{H}, \mathrm{CH}-\mathrm{CH}\left(\mathrm{CH}_{3}\right)\right), 1.574$ (d, $\left.2 \mathrm{H}, \mathrm{CH}_{2}-\mathrm{CH}_{2} \mathrm{CH}\left(\mathrm{CH}_{3}\right)\right), 3.48(\mathrm{~s}, 1 \mathrm{H}, \mathrm{OH}), 3.63\left(\mathrm{~m}, \mathrm{H}, \mathrm{CH}-\mathrm{CH}(\mathrm{OH}) \mathrm{CH}_{2}\right), 7.04-7.28(\mathrm{~m}$, aromatic protons) figure (8).

The mass spectrum showed a molecular ion peak at $\mathrm{m} / \mathrm{z} 384(0.58 \%)$ which is corresponding to the molecular formula $\left(\mathrm{C}_{21} \mathrm{H}_{18} \mathrm{O}_{7}\right)$ figure: 9 . 
Purification of The Antitumor Active Metabolite...

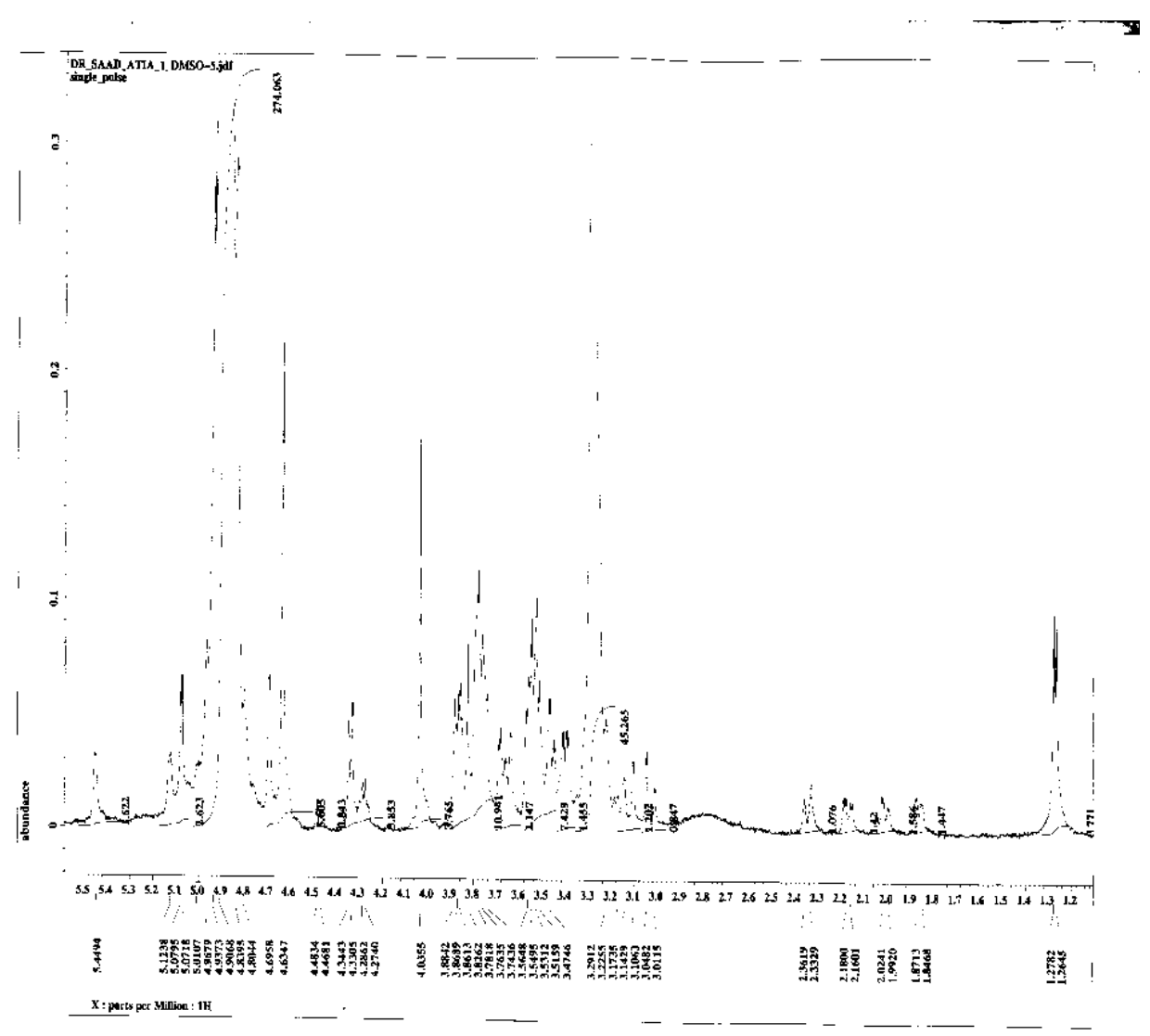

Figure(8): 1HNMR spectrum of the compound $(\mathrm{C}-1)$ in $\mathrm{CDCl}_{3}$

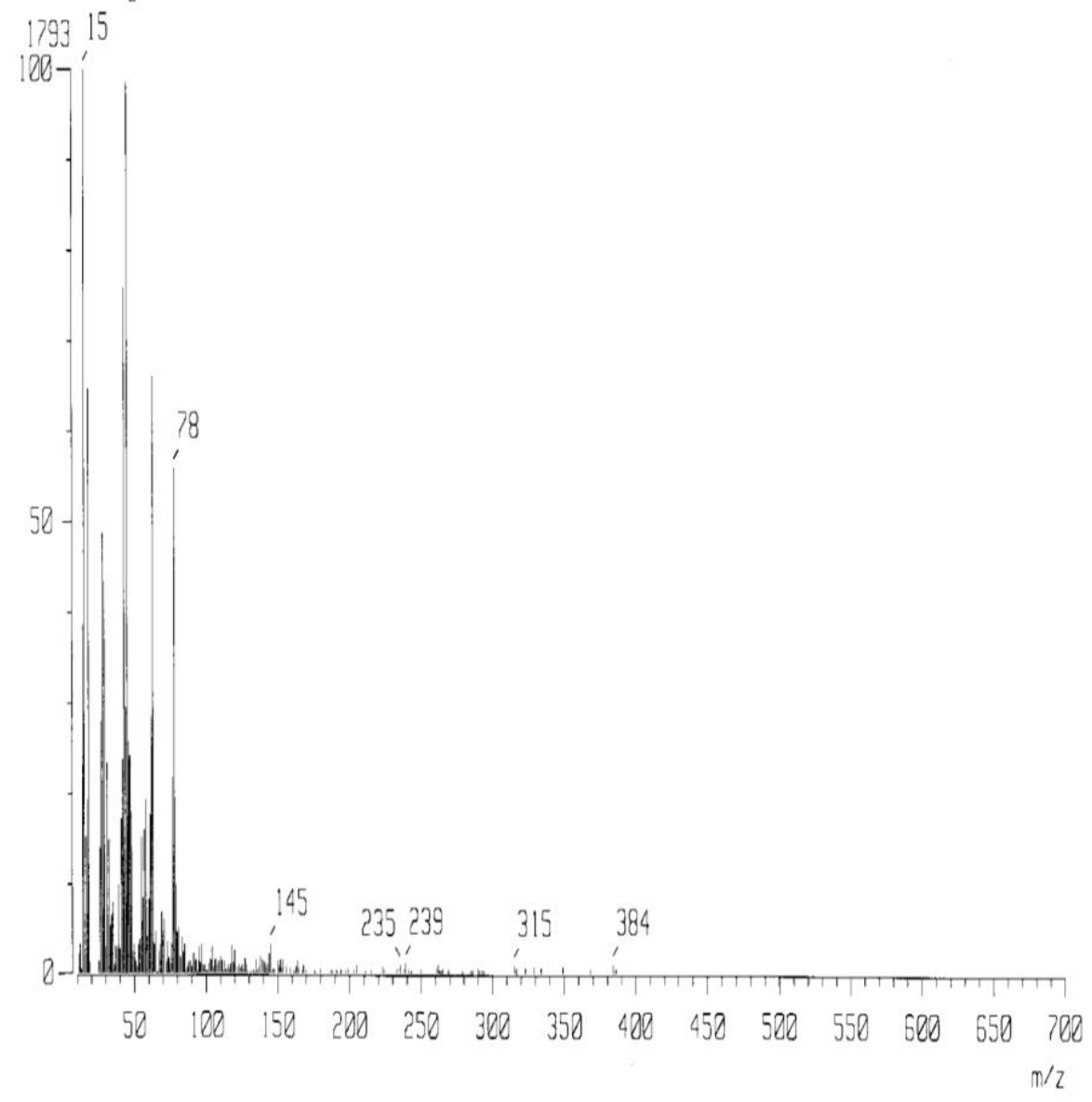

Figure (9): Mass spectrum of the purified compound 
From the previous data it is clear that the suggested chemical structure of the purified compound as the following:<smiles>COc1cccc2c1C(=O)c1c(O)c3c(c(O)c1C2O)C[C@H](C(=O)CO)CC3</smiles>

5,6,8,11-tetrahydroxy-8-hydroxyacetyl-1-methoxy-7,8,9,10-tetrahydrotetracene-12-dione On the basis of comparative study of the recorded chemical composition and physical properties of the purified compound produced by Streptomyces xylophagus Ha.Ph-7 and by consulting the recommended identification keys of antibiotics such as [30] it could be stated that, the purified active compound is belonging to anthracyclines antibiotic group as a derivative of Daunomycin (Aglycone of daunorubicin, the prototypical anthracyclines) (Arcamone et al., 1964 and Barbieri et al., 1964).

\section{REFERENCES:}

1. Ventura M, Canchaya C, Tauch A, Chandra G, Fitzgerald GF, Chater KF et al. Genomics of Actinobacteria: Tracing the evolutionary history of an ancient phylum. Microbiol Mol Biol Rev 2007;71:495-548.

2. Ghanem NB, Sabry SA, El-Sherif ZM, Abu ElEla GA. Isolation and enumeration of marine actinomycetes from seawater and sediments in Alexandria. J Gen Appl Microbiol 2000;46:105111.

3. Zheng Z, Zeng W, Huang Y, Yang Z, Li J, Cai $\mathrm{H}$ et al. Detection of antitumor and antimicrobial activities in marine organism associated actinomycetes isolated from the Taiwan Strait, China. FEMS Microbiol Lett 2000;188:87-91.

4. Fiedler HP, Bruntner C, Bull AT, Ward AC, Goodfellow M, Potterat O, Puder C, Mihm G. Marine actinomycetes as a source of novel secondary metabolites. Antonie van Leeuwenhoek 2005;87:37-42.

5. Ward AC, Bora N. Diversity and biogeography of marine actinobacteria. Curr Opin Microbiol 2006;9:1-8.

6. Fenical W, Jensen PR. Developing a new resource for drug discovery: marine actinomycete bacteria. Nat Chem Biol 2006;2:666-73.

7. Panthom-Aree W, Stach JEM, Ward AC, Horikoshi K, Bull AT, Goodfellow M. Diversity of actinomycetes isolated from challenger deep sediment $(10,898 \mathrm{~m})$ from the Mariana Trench. Extremophiles 2006;10;181-89.

8. Bull AT, Stach JEM. Marine actinobacteria: new opportunities for natural product search and discovery. Trends Microbiol 2007;15:491-99.

9. Gontang EA, Fenical W, Jensen PR. Phylogenetic diversity of Gram-positive bacteria cultured from marine sediments. Appl Environ Microbiol 2007;73:3272-82.

10. Bredholdt H, Galatenko OA, Engelhardt K, Fjærvik E, Terekhova LP, Zotchev SB. Rare actinomycete bacteria from the shallow water sediments of the Trodheim fjord, Norway: isolation, diversity and biological activity. Environ Microbiol 2007;9:2756-64.

11. Jensen PR, Lauro FM. An assessment of actinobacterial diversity in the marine environment. Antonie van Leeuwenhoek 2008;94;51-62.

12. Anzai K, Nakashima T, Kuwahara N, Suzuki R, Ohfuku Y, Takeshita S, et al. Actinomycete bacteria isolated from the sediments at coastal and offshore area of Nagasaki Prefecture, Japan: diversity and biological activity. J Biosci Bioeng 2008;106:215-17.

13. Hong K, Gao AH, Xie QY, Gao H, Zhuang L, Lin HPet al. Actinomycetes for marine drug discovery isolated from mangrove soils and plants in China. Mar Drugs 2009;7:24-44.

14. Maldonado LA, Fragoso-Yáñez D, PérezGarcía A, Rosellón-Druker J, Quintana ET. Actinobacterial diversity from marine sediments collected in México. Antonie van Leeuwenhoek 2009;95:111-20.

15. Baltz RH. Renaissance in antibacterial discovery from actinomycetes. Curr Opin Pharmacol 2008;8;557-63.

16. Blunt JW, Copp BR, Munro MH, Northcote PT, Prinsep MR. Marine natural products. Nat Prod Rep 2006;3:26-782.

17. Mayer AM, Rodríguez AD, Berlinck RG, Hamann MT. Marine pharmacology in 2003-4: Marine compounds with anthelmintic antibacterial, anticoagulant, antifungal, anti-inflammatory, antimalarial, antiplatelet, antiprotozoal, antituberculosis, and antiviral activities; affecting the cardiovascular, immune and nervous systems, and other miscellaneous mechanisms of action. Comp Biochem Physiol 2007;145:553-81.

18. Williams PG. Panning for chemical gold: marine bacteria as a source of new therapeutics. Trends Biotechnol 2009;27:45-52. 
19. Blunt JW, Copp BR, Hu WP, Munro MH, Northcote PT, Prinsep MR. Marine natural products. Nat Prod Rep 2009;26:170-244.

20. Fenical W, Sethna KM, Lloyd GK. Marine microorganisms as a developing resource for drug discovery. Pharm News 2002;9:489-94.

21. Shen B. Polyketide biosynthesis beyond the type I, II and III polyketide synthase paradigms. Curr Opin Chem Biol 2003;7: 285-295.

22. Menarini R, Via T, Speri P. from the pigments of the actinomycetes to third generation antitumor anthracyclines. Biochimie 1998;80:201-206.

23. Weiss RB. The anthracyclines: Will we ever find a better doxorubicin? Semin. Oncol 1992;19:670-686.

24. Takimoto CH, Calvo E. 2008: "Principles of Oncologic Pharmacotherapy" in Pazdur, R.; Wagman, L.D.; Camphausen, K.A. and Hoskins, W.J. (Eds). Cancer Management: A Multidisciplinary Approach. 11 ed.

25. Eagle H. Amino acid metabolism in mammalian cells in tissue culture. Science 1959;130:432-7.
26. FLIS Sylwia, GNYSZKA Agnieszka, MISIEWICZ-KRZEMIŃSKA Irena, SPLAWIŃSKI Jacek. Decytabine enhances cytotoxicity induced by oxaliplatin and 5fluorouracil in the colorectal cancer cell line Colo205. Cancer Cell International. April 2009;27(9):1-10.

27. Suffness M, Pezzuto JM. Assays related to cancer drug discovery. In: Hostettmann K (Ed.), Methods in Plant Biochemistry: Assays for Bioactivity. Academic Press, London. 1990;6:71133 ,.

28. Quah BA. Cytotoxic activity of Goniothalamin on different types of cancer cell lines. 1995; B.Sc. Thesis, Biotechnology, University Putra Malaysia. 29. Mans DRA, Rocha AB, Schwartsmann G. Anticancer drug discovery and development in Brazil: targeted plant collection as a rational strategy to acquire candidate anticancer compounds. The Oncologist. 2000;5(3):185-198.

30. Umezawa $H$. Recent advances in bioactive microbial secondary metabolites. J. Antibiotic. Suppl.

1977;30:138-163.31.

Table (1): Gradient elution of the crude extract obtained from Streptomyces xylophagus Ha.Ph-7

\begin{tabular}{|c|c|c|}
\hline Solvent system & Ratio (v/v) & Volume of eluates (ml) \\
\hline n-Hexane & $100 \%$ & 200 \\
\hline \multirow{4}{*}{ n-Hexane : Ethyl acetate } & $100: 0$ & 200 \\
\cline { 2 - 3 } & $95: 5$ & 600 \\
\cline { 2 - 3 } & $90: 10$ & 400 \\
\cline { 2 - 3 } & $80: 20$ & 600 \\
\cline { 2 - 3 } & $70: 30$ & 200 \\
\cline { 2 - 3 } & $50: 50$ & 400 \\
\cline { 2 - 3 } & $30: 70$ & 400 \\
\cline { 2 - 3 } & $0: 100$ & 200 \\
\hline Methanol & $100 \%$ & 200 \\
\hline
\end{tabular}

Table (2): Fractions weight of the crude extract obtained from Streptomyces xylophagus Ha.Ph-7.

\begin{tabular}{||c|c|c|c||}
\hline Fraction No. & Collected fractions & $\begin{array}{c}\text { Weight } \\
(\mathbf{m g})\end{array}$ & \% Composition in dry extract \\
\hline S-1 & $1-2$ & 20 & $0.66 \%$ \\
\hline S-2 & $3-10$ & 80 & $2.66 \%$ \\
\hline S-3 & $11-17$ & 100 & $3.33 \%$ \\
\hline S-4 & $18-22$ & 40 & $1.33 \%$ \\
\hline S-5 & $23-24$ & 65 & $2.16 \%$ \\
\hline S-6 & $25-28$ & 120 & $4.00 \%$ \\
\hline S-7 & $29-31$ & 30 & $1.00 \%$ \\
\hline S-8 & $32-37$ & 135 & $4.5 \%$ \\
\hline S-10 & $38-45$ & 61 & $2.03 \%$ \\
\hline S-11 & $46-47$ & 76 & $2.53 \%$ \\
\hline S-12 & $48-51$ & 111 & $3.7 \%$ \\
\hline S-13 & $52-61$ & 189 & $6.30 \%$ \\
\hline
\end{tabular}

$* \mathrm{~S}=$ Streptomyces. 